\title{
Socio-economic factors affecting home gardens as a livelihood strategy in rural areas of the Eastern Cape province, South Africa
}

Mdiya, $\mathrm{L}^{1}$ and Mdoda, $\mathrm{L}^{2}$

Corresponding Author: L. Mdiya. Correspondence Email: 1mdiya@ufh.ac.za

\begin{abstract}
Home gardens have been identified as one of the possible ways of producing food and offer great solutions to some of the issues surrounding poverty alleviation and improving food security in rural areas. However, home gardens' potential as a living strategy has not been recognized and affected by many factors. Therefore, the study examines socio-economic factors influencing home gardens as a living strategy in rural areas of the Eastern Cape Province. The study was conducted in the Eastern Cape Province rural areas, where data was collected from 200 households using snowball sampling. The study made use of descriptive and logit regression models for analysis. The study results reveal that female households actively participated in home gardens with an average of 46 years. Households were landowners with an average farm size of $3 \mathrm{Ha}$ and owning farm assets. Home gardens contributed immensely to households by providing food for home consumption and generating income from crops and vegetables. The study concludes that Socioeconomic factors were the factors influencing home gardens as the living strategy in rural areas. Therefore, the study recommends the provision of external personnel in rural areas to assist home gardeners in improving their productivity.
\end{abstract}

Keywords: Eastern Cape Province, home gardens, living strategy

\section{INTRODUCTION}

The massive population of people living in developing countries suffers from hunger, food starvation, and food insecurity due to the lack of food produced (Galhena, Freed, and Maredia, 2013). Therefore, there's a continuous need to increase food production and develop different strategies to enhance food production. In most rural areas of South Africa, home gardens have been identified as one of the possible ways of improving food security and offer great solutions to some issues surrounding poverty alleviation and local income generation. For many years now, there has been increasing concern to reinforce local food production to mitigate the adverse effect

\footnotetext{
${ }^{1}$ Lecturer, Department of Agricultural Economics, University of Fort Hare, P/bag X 1314, Alice, 5700. South Africa, Email Address: 1mdiya@ufh.ac.za, ORCID: http://orcid.org/0000-0002-2207-9261.

2 Senior Lecturer, Department of Agricultural Economics, University of KwaZulu-Natal, P/B X01, Scottsville, Pietermaritzburg, 3209. South Africa, Email Address: MdodaL@ukzn.ac.za, ORCID: https://orcid.org/0000-0002$\underline{5402-1304 .}$
} 
of global food shocks and food prices to assist the rural poor. This, however, led to the implementation of home gardens as they play a significant role in reducing the risk of food insecurity for rural and urban poor households (Baiphethi and Jacobs, 2010). Literature suggests that home gardens are small portions of land around the household or within walking distance from the family home used for farming vegetables or other crops such as maize. This is one of the most important sources of food in many rural areas in developing countries and can significantly contribute to meeting daily household needs for better nutrition and health (Musotsi et al. 2008). However, most home gardeners have not managed to produce enough food as much as they would have liked for markets as they prioritize food for home consumption for their households (Galhena et al. 2013). According to Oluwasola, Monde, and Sunday (2013), home gardens are an essential source of food and are an essential means of on-farm conservation of resources and remain an essential avenue for food production for most rural households. However, in a study conducted by Rodrigue et al. (2015) on factors affecting home gardens, literature indicated that the home gardens' socio-economic, demographic, local context, and ecological conditions positively contribute to rural livelihood. Some of these factors include home garden ownership, gender, age, and lack of financial resources. With that background, there's an increasing need to investigate socio-economic factors affecting home gardens as a living strategy in rural areas of the Eastern Cape Province.

\section{METHODOLOGY}

\subsection{Study area and research design}

The study was conducted in the Eastern Cape Province of South Africa. Located in the southeastern part of South Africa, the Eastern Cape Province is the second largest Province in South Africa. The Province is one of the poorest provinces in the country and was formed in 1994 out of the Xhosa homelands of Transkei and Ciskei, together with the eastern portion of the Cape Province. Eastern Cape Province is the third-highest inhabited region in South Africa with 6.562 million (12.7\%) after Gauteng and KwaZulu Natal provinces, which are estimated to have populations of $12,272,263$ million (23.7\% of national) and 10,267,300 (10.8\%) respectively (Mdoda and Obi, 2019; Hlomendlini, 2015). The Eastern Cape stretches along some 800km of the south-eastern shores of South Africa. It is a region of supreme natural beauty, particularly its rugged cliffs and the rolling green hills of the northeast of the Eastern Cape Province. The Province consists of 169,580 square kilometers, 14\% of South Africa's landmass (ECDC, 2013).

The climatic conditions of the Eastern Cape coastal areas lie between the sub-tropical conditions predominant in KwaZulu-Natal and the Mediterranean climate of the Western Cape. The western side of the Province, the Karoo region, experiences extended scorching summers and temperate winters. The Eastern side of the Province has high elevations of the Great Escarpment towards Lesotho and the Free State frequently experiences snow in winter. The Province experiences a 
bimodal precipitation pattern, with a winter rainfall zone in the west and a summer rainfall zone in the east. Due to varying rainfall seasons, growing times also differ throughout the Province. The Province's climatic conditions favor agricultural production, especially crop, vegetables, citrus, and livestock (cattle and sheep).

The Province was selected because households partake in farming activities as farmers and home gardens and have access to water harvesting techniques (Monde et al., 2006). Additionally, rural households are deriving their livelihoods from practicing farming through home gardening. The study used a cross-sectional design where it collects data at one point in time from respondents in the region.

\subsection{Sampling procedure and sample size}

The study intended to cover most of the backyard and home gardens within the rural communities. The study used both qualitative and quantitative approaches with random and snowball sampling used to select respondents. The study was done in two District Municipalities, Amatole and OR Tambo District Municipalities, randomly selected. King Sabata Dalindyebo and Raymond Mhlaba Municipality were selected as Local Municipalities in each district municipality. This procedure permitted the researcher to select respondents through referrals to make it easy and quick to find respondents making a livelihood from home gardens, significantly contributing to households through food security and income generation. Subjects from reliable sources select a sample of respondents who had experience and knowledge about home gardens. The sample size of 200 was selected from households actively involved in home gardens in the study area.

\subsection{Data collection}

The study made use of primary data, which was collected through a survey. A structured questionnaire was developed as the main data collection tool. The questionnaire was designed and divided into sections informed by the objectives of the study. The questionnaire was pre-tested to check whether it was suitable for the study and check for some errors. It is also assisted by training the enumerators so that they can be familiar with the questionnaire. The 20 respondents used for the pre-testing of the questionnaire were not used in the main survey and were pre-tested in Ntselamanzi township. Data was collected successively over four months of 10 July 2018 to 25 October with the help of an enumerator from the study areas. Household heads of the households were interviewed using a face-to-face arrangement. In the absence of the household head, the spouse or any family member who is directly involved in the home gardening activities were interviewed. The interviews were carried out in IsiXhosa (the local language of the people) to reduce misinterpretations and gain households' confidence. 
Vol. 49 No. 3, 2021: 1-15

http://dx.doi.org/10.17159/2413-3221/2021/v49n3a12823

(License: CC BY 4.0)

\subsection{Data}

This section represents data that was collected from smallholder vegetable farmers.

TABLE 1. Description of variables used in the study

\begin{tabular}{|c|c|c|c|}
\hline Variable & Description & Measurement & Expected sign \\
\hline \multicolumn{4}{|c|}{$\begin{array}{l}\text { Independent } \\
\text { variables }\end{array}$} \\
\hline $\mathrm{X}_{1}$ & Gender of the farmer & $1=$ male, $0=$ otherwise & - \\
\hline $\mathrm{X}_{2}$ & Age of the farmer & Actual years & - \\
\hline $\mathrm{X}_{3}$ & $\begin{array}{l}\text { Marital status of the } \\
\text { farmer }\end{array}$ & $\begin{array}{l}1=\text { married, } 0= \\
\text { otherwise }\end{array}$ & + \\
\hline $\mathrm{X}_{4}$ & $\begin{array}{l}\text { Family size of the } \\
\text { farmer }\end{array}$ & $1=>4,0=$ otherwise & + \\
\hline $\mathrm{X}_{5}$ & $\begin{array}{l}\text { Years spent in school } \\
\text { by the farmer }\end{array}$ & $\begin{array}{l}1=\text { actual years spent in } \\
\text { school, } 0=\text { otherwise }\end{array}$ & + \\
\hline $\mathrm{X}_{6}$ & $\begin{array}{l}\text { Household source of } \\
\text { income by the farmer }\end{array}$ & $\begin{array}{l}1=\text { social grants, } 0= \\
\text { otherwise }\end{array}$ & - \\
\hline $\mathrm{X}_{7}$ & $\begin{array}{l}\text { Farming years by the } \\
\text { farmer }\end{array}$ & $\begin{array}{lll}\begin{array}{l}\text { Actual } \\
\text { farming }\end{array} & \text { years of } \\
\end{array}$ & + \\
\hline $\mathrm{X}_{8}$ & $\begin{array}{l}\text { Distance to the } \\
\text { agricultural } \\
\text { marketing center }\end{array}$ & $\begin{array}{l}1=10 \mathrm{~km}, \quad 0= \\
\text { otherwise }\end{array}$ & - \\
\hline $\mathrm{X}_{9}$ & $\begin{array}{l}\text { Access to extension } \\
\text { agents by the farmer }\end{array}$ & $\begin{array}{l}1=\text { access to extension } \\
\text { agents, } 0=\text { otherwise }\end{array}$ & + \\
\hline $\mathrm{X}_{10}$ & $\begin{array}{l}\text { Access to a financial } \\
\text { institution by the } \\
\text { farmer }\end{array}$ & $\begin{array}{l}1=\text { access to finance, } 0 \\
=\text { otherwise }\end{array}$ & - \\
\hline $\mathrm{X}_{11}$ & $\begin{array}{l}\text { Member of farm } \\
\text { organization }\end{array}$ & $\begin{array}{l}1=\text { member of farm } \\
\text { organization, } 0= \\
\text { otherwise }\end{array}$ & + \\
\hline $\mathrm{X}_{12}$ & $\begin{array}{l}\text { Household monthly } \\
\text { income }\end{array}$ & $\begin{array}{l}1=>1500,00 \\
\text { otherwise }\end{array}$ & + \\
\hline $\mathrm{X}_{13}$ & $\begin{array}{l}\text { Occupation by the } \\
\text { household head }\end{array}$ & $\begin{array}{l}1=\text { full time farmer, } 0= \\
\text { otherwise }\end{array}$ & + \\
\hline
\end{tabular}

\subsection{Analytical framework}

This study adopted the Logit model to measure socio-economic factors affecting home gardens as a living strategy for rural households. The word "logit" denotes the log-likelihoods, which presupposes the likelihood of declining interest in 1 of 2 groups on the clear elastic of concentration 
(Wooldridge 2009). The study uses this method as the answer is binary, where households are either participate or do not participate in home gardens. Mdoda et al. (2019) specified that the logistic regression dimension could estimate likelihoods associations for all of the independent variables in the model. The logistic regression model is suitable to a wider variety of exploration circumstances than discriminant examination. The logistic regression model is one of the most widely used models to investigate the independent effect on binomial outcomes. A logit regression was used because it enforces inception and relation effects that permit the investigation of social interaction. Additionally, the regression is very flexible and easily applicable, and the interpretation of the results is straightforward and meaningful (Mcata, 2019; Montshwe, 2006). Ekepu and Tirivanhu (2016) and Taboka (2016), this model make use of the highest likelihood method.

For this paper, two choices existed and were accessible, specifically "ownership/participating in home gardens" or "not owning/participating in home gardens" a twofold regression was established up to explain $\mathrm{Y}=1$ for a state anywhere the household own home garden and $\mathrm{Y}=0$ for states wherever the household does not own home garden foundations. Assuming that $\mathrm{X}$ is a trajectory of eloquent variables and $\mathrm{p}$ is the likelihood that $\mathrm{Y}=1$, dualistic probabilistic associations as quantified by Wooldridge (2009). This can be measured as follows:

$p(Y=1)=\frac{e^{\beta \chi}}{1+e^{\beta \chi}}$

$p(Y=0)=1-\frac{e^{\beta \chi}}{1+e^{\beta \chi}}=\frac{1}{1+e^{\beta \chi}}$

\section{Where}

Calculation (2) is the lesser answer level, that is, the prospect that a household own a home garden; this will be the likelihood to be demonstrated through the logistic technique by settlement. Together, the calculations demonstrate the consequence of the logit alteration of the likelihood's proportions, which can otherwise be symbolized as:

$\log i t[\theta(x)]=\log \left[\frac{\theta(x)}{1-\theta(x)}\right]=\alpha+\beta_{1} X_{1}+\beta_{2} X_{2}+\beta_{3} X_{3}+\cdots \ldots \ldots \ldots+\beta_{n} X_{n}$

Besides thus authorizing its estimate as a direct regression for which the ensuing descriptions relate:

$\Theta=$ logit alteration of the likelihoods fraction; = the interrupt span of the model

$\beta=$ explanatory variables exhibited and

$\mathrm{Xi}=$ forecaster variables.

The previous processes were possible within the STATA. In relative to equation (3), the examination created the odds relations exhausting the supreme probability technique. The logistic deterioration in this study can be stated as follows:

$Y_{1}=\alpha+\beta_{1} X_{1}+\beta_{2} X_{2}+\beta_{3} X_{3}+\beta_{4} X_{4}+\beta_{5} X_{5} \ldots+$

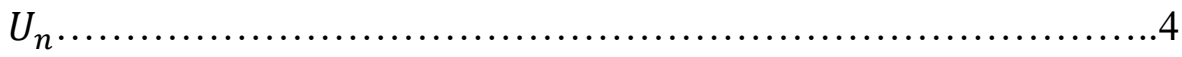


Where

Yi (ownership of home garden) $=$ the reliant on variable distinct as owning home garden $=1$ and 0 otherwise

$\alpha=$ constant and capture of the equation

$\beta=$ slope of the discrete predictor (or instructive) variables demonstrated

$\mathrm{Xi}=$ forecaster variables.

$U_{n}=$ alteration error term.

\section{RESULTS AND DISCUSSION}

This section discusses study results from the two analytical frameworks used to examine socioeconomic factors affecting home gardens as a living strategy in rural areas of the Eastern Cape. The households' characteristics were examined using descriptive statistics, factors affecting home garden ownership, and a living strategy was measured using Logistic regression.

\subsection{Socio-economic characteristics of rural households}

The study results reveal that majority of home gardeners in the Eastern Cape were female households with a proportion of $68 \%$ while male counterparts with $32 \%$. These results agree with Matebeni (2018) and Ortmann and King (2006) that the majority of the households are females who are actively participating in home gardens, while male counterparts migrate to cities for nongovernment jobs. The study results reveal that the average age of the households was 46 years, with a family size of 5 people per household. The findings were in line with Adhikari (2005), who stated that older people are generally unable to perform aggressively in the agricultural sector, especially home gardens, as their body does not allow them to work the garden. Results reveal that about $70 \%$ of the households were married and that played a key role in providing family labor for households who participate in the home gardens. Etwire et al. (2013) argued that the higher number of married households is because most rural people, especially women, get married at an early age. Household heads spent 12 years in school, which is very useful in interpreting necessary farming information and innovative techniques. These results agree with Ngema (2017) that educated households use such knowledge to improve and apply it in their home gardens. About $75 \%$ of the households produce their maize and vegetables, while the remaining $25 \%$ buy vegetables and maize from urban markets. 
S. Afr. J. Agric. Ext.

Mdiya \& Mdoda

Vol. 49 No. 3, 2021: 1-15

http://dx.doi.org/10.17159/2413-3221/2021/v49n3a12823

(License: CC BY 4.0)

TABLE 2. Demographic characteristics of households

\begin{tabular}{|c|c|c|}
\hline Variables & Frequency & Percentage \% \\
\hline \multicolumn{3}{|l|}{ Sex of household head } \\
\hline Male & 64 & 32 \\
\hline Female & 136 & 68 \\
\hline \multicolumn{3}{|l|}{ Marital status } \\
\hline Married & 140 & 70 \\
\hline Single & 40 & 20 \\
\hline Window & 20 & 10 \\
\hline \multicolumn{3}{|l|}{ Assets ownership } \\
\hline Yes & 180 & 90 \\
\hline No & 20 & 10 \\
\hline \multicolumn{3}{|l|}{$\begin{array}{lll}\begin{array}{l}\text { Participate } \\
\text { gardens }\end{array} & \text { in } & \text { home } \\
\end{array}$} \\
\hline Yes & 144 & 72 \\
\hline No & 56 & 28 \\
\hline \multicolumn{3}{|l|}{ Crops grown } \\
\hline Maize & 90 & 45 \\
\hline Vegetables & 110 & 55 \\
\hline \multicolumn{3}{|l|}{$\begin{array}{l}\text { Reasons for participating } \\
\text { in home gardens }\end{array}$} \\
\hline Home consumption & & 75 \\
\hline Marketable & & 25 \\
\hline \multicolumn{3}{|l|}{ Extension services } \\
\hline Yes & 160 & 80 \\
\hline \multirow[t]{2}{*}{ No } & 40 & 20 \\
\hline & Continuous variables & Mean \\
\hline Age of the household head & Years & 46.02 \\
\hline Household size & Persons & 5.10 \\
\hline $\begin{array}{l}\text { Years spent in school by the } \\
\text { household head }\end{array}$ & Years & 12.20 \\
\hline Farm experience & Years & 10.00 \\
\hline Household income & Rands & 8300.00 \\
\hline Farm size & Hectares & 3.40 \\
\hline
\end{tabular}

The study found that $72 \%$ of the rural households-maintained home gardens, with the rest being involved in off-farm activities as they were not interested in practicing agriculture. Households were landowners with a farm size of $3 \mathrm{Ha}$ per household and were staying in pastoral areas. The 
total average household income was R8 300.00 per month, where $60 \%$ of it came from off-farm income, and the remaining came from home gardens (30\%) and social grants. Households, as a result, did not have any form of credit to assist in participating in home gardens. Most households have a farming experience of 10 years in participating in home gardens and deriving living through home gardens. The majority of the households (about 90\%) owned assets they were using in their home gardens, such as hand hoe, fork spade, rake, watering can, cell phones, and wheelbarrow.

\subsection{Contribution of home gardens}

Home gardens are essential for rural dwellers because they derive their livelihoods from practicing farming. This form of farming is the traditional one in which rural inhabitants were taught by their great parents and less expensive farming, which is mainly for home consumption. Home gardens have proved crucial in rural areas in reducing poverty, food insecurity, and generating income. Table 3 illustrates the contribution of home gardens to rural dwellers.

TABLE 3. Contribution of home gardens

\begin{tabular}{|l|l|l|}
\hline Home garden contribution & frequency & Percentage \\
\hline Home consumption food & 160 & $74 \%$ \\
\hline Income generation & 30 & $20 \%$ \\
\hline $\begin{array}{l}\text { Both Home consumption and } \\
\text { income }\end{array}$ & 10 & $6 \%$ \\
\hline
\end{tabular}

The study results reveal that home gardens contribute immensely as a living strategy in pastoral areas of the Province. The study found home consumption to be the leading home garden contributor with a proportion of $74 \%$. This emphasizes the importance of home gardens in providing food for the well-being of the household. The results are in line with Mokone (2016), who found out that home gardens contribute immensely to providing food so that the household can be food secure and generate income. The majority of rural households are strictly involved in home gardens to support and take care of their families through food supply as they do not have any other form of living strategy. The study also reveals that some households are generating income from home gardens with a proportion of $20 \%$. These households only sell the remaining surpluses left after the household consumption share has been decided. These households only sell locally. About $6 \%$ of households obtain home consumption and income. This form of contribution by home gardens is not widely guaranteed many benefits and is only practiced by well-off households in terms of off-farm income. 


\subsection{Challenges faced by home garden owners}

Home gardens contribute significantly to households through livelihoods generation for most rural dwellers in the Province. However, home gardeners are faced with numerous challenges which affect their gardens adversely and reduce their contribution. Table 4 reports challenges faced by home garden owners.

TABLE 4. Challenges faced by home garden owners

\begin{tabular}{|l|l|l|}
\hline $\begin{array}{l}\text { Challenges faced by home } \\
\text { garden owners }\end{array}$ & Frequency & Percentage \\
\hline Lack of inputs & 183 & $86 \%$ \\
\hline Water availability & 195 & $96 \%$ \\
\hline Credit constraints & 170 & $83 \%$ \\
\hline Theft & 150 & $75 \%$ \\
\hline Diseases & 169 & $80 \%$ \\
\hline Poor soil fertility & 96 & $62 \%$ \\
\hline
\end{tabular}

The study results reveal that water availability is the main challenge affecting and constraining home gardeners with a proportion of $96 \%$. Most rural areas have water challenges as they do not have taps; instead, they depend on rivers and streams for water. These results are similar to Mokone (2016), who found that water is the main crisis in rural areas as most villages do not have taps. Most households cannot fetch water from rivers and streams for home consumption and garden irrigation because of their age. The second challenge is the lack of inputs with a proportion of $86 \%$. This is one of the challenges facing households because they lack the finance to purchase farming inputs since they depend mainly on social grants. Credit constraints (83\%) play a significant role in farming, as ownership of assets heavily depends on credit access. This causes rural households to use absolute and traditional methods for farming as they cannot afford innovative farm materials for home gardening. The spread of diseases (80\%) is increasing in rural areas because most households do not know about diseases affecting their crops and vegetables. There is a high rate of theft $(72 \%)$ in rural areas, which is an increasing challenge for home gardeners. This is the rising challenge because most home gardeners are headed by females, which makes them exposed to theft than home gardeners headed by males. Another reason for theft is the lack of fencing among rural households, which exposes them to theft. Finally, poor soil fertility (62\%) is experienced by most home gardens, which reduces their productivity and participation.

\subsection{Factors influencing home gardens}

The study used Logit regression analysis to measure the socio-economic factors impelling home gardens as a living strategy in rural areas. The Pseudo- $\mathrm{R}^{2}$ and the Likelihood ratio Chi-square are used to evaluate the model fit and how well the model ordered defendants appropriately built on assessed likelihoods. The Pseudo- $\mathrm{R}^{2}$ shows that the dependent variables included in the Logit 
model explained $86 \%$ of the variations in participating in home gardens. The likelihood ratio Chisquare of 165.789 with a p-value of 0.0000 expresses that our model is statistically substantial. The R Squared (86\%) and adjusted R square (80\%) recommend a good fit (Table 3). The study reveals that socio-economic factors were the only factors influencing home gardens (generating income from home gardens) in the study area. All of these exploratory variables were significant at $1 \%$ and $5 \%$ significant levels, respectively. Table 5 shows factors affecting home gardens in the study area.

TABLE 5. Factors influencing home gardens

\begin{tabular}{|l|l|l|l|}
\hline Variable & Coefficient & Standard Error & $\mathbf{P}>\mathbf{z}$ \\
\hline Age & -0.0789 & 0.0567 & $0.002^{* * *}$ \\
\hline $\begin{array}{l}\text { Location and land } \\
\text { access }\end{array}$ & 0.0305 & 0.0231 & $0.000^{* * *}$ \\
\hline Years spent in school & 0.0897 & 0.0543 & $0.028^{* *}$ \\
\hline Off-farm income & -0.0674 & 0.0721 & $0.001^{* * *}$ \\
\hline $\begin{array}{l}\text { Total household } \\
\text { monthly income }\end{array}$ & 0.0529 & 0.0376 & $0.008^{* * *}$ \\
\hline $\begin{array}{l}\text { Land ownership and } \\
\text { accessibility }\end{array}$ & 0.0954 & 0.0768 & $0.048^{* *}$ \\
\hline Farm size & -0.0561 & 0.0624 & $0.035^{* *}$ \\
\hline Household size & -0.0452 & 0.0632 & $0.037^{* *}$ \\
\hline constant & 0.0865 & 0.0632 & 0.985 \\
\hline $\begin{array}{l}\text { Number of observers }=200 \\
\text { P.Chi }{ }^{2}=0.000 \\
\mathrm{R}^{2}=0.0863 \\
\text { Adjusted } \mathrm{R}^{2}=80 \%\end{array}$ & Log likelihood= -163.876 \\
\hline
\end{tabular}

Note: $* * *$ and $* *$ significant level of $1 \%$ and $5 \%$ respectively

The study results found these exploratory variables to be the main factors affecting home gardens as a living strategy of rural households. The household age has a negative coefficient and is statistically significant at $1 \%$. This implies that a unit increase of 1 year in age will induce a decrease in income earned by $7.89 \%$ from participating in home gardens. These results suggest that the more age of the household increase, the involvement in home gardens decreases as households lose strength and manpower to work the home garden. These results are in line with Ngema (2017), who specified that the likelihood of a household participating in its food gardens (such as food security intervention program) decreases with an increase in age of the household head involved in home gardens. This further means that there is no direct relationship between the age of the households and home garden ownership. 
Location and land access were found to have a positive coefficient and were statistically significant at $1 \%$. This suggests that a unit increase of $1 \%$ in location and having access to land so that you can practice garden led to an increased income earned 3.05 when a household is involved in home garden involvement. This suggests that if people are residing in rural areas, they stand a better chance of owning a home garden than their counterparts who are residing in urban areas as there is land availability to practice home garden than in urban areas tend to have small or no garden space, with theft so high that it is difficult to harvest anything for all the work a household have done. These results are in line with Mcata (2019), who found that living in rural areas increases participation in home gardens as residing in rural areas increases the chances of owning bigger land than urban counterparts, increasing the chances of being involved in home gardens. This is impossible in urban areas as people tend to have small or no garden space, with theft so high that it is difficult to harvest anything for all the work households have done. Ownership of home gardens in rural areas is viewed as an identity by households and a way of maintaining their roots of Africanism.

Years spent in school were found to have a positive coefficient and were statistically significant at $5 \%$. This suggests that there is a direct relationship between years spent in school and ownership of home gardens. This means an additional year in years spent in school led to an increase in income earned 8.97 from home gardens participation and ownership. Years spent in school increase the involvement in home gardens because households have learned about the importance of home gardens in reducing food security and poverty alleviation. These results have similar findings with Nontu and Taruvinga (2021) and Muchara (2010) that years spent in school exposes and increases chances of the household being involved in home gardens as schooling made households more open to innovation and knowledge about home garden benefits and farming techniques. Years spent in school have equipped rural households with all the necessary information (such as applying modern farm technology) essential in increasing home garden production and benefits that will change the households' living conditions.

Off-farm income was found to have a negative coefficient and was statistically significant at $1 \%$. This implies that a unit increase of $1 \%$ in off-farm income decreased home garden participation by $0.0674 \%$. The results reveal that having an off-farm income reduces participation in home gardens as households rely heavily on off-farm activities such as employment. This suggests that households who have another source of income from other activities tend not to participate in home gardens. Household size was found to have a negative coefficient and was statistically significant at $5 \%$. This implies that an increase of $1 \%$ in household size led to a decrease in home garden participation by $0.0452 \%$. This means the larger the household size, the less involvement in home gardens as they tend to invest more in other activities away from home gardens. 
Total household monthly income from home gardening was found significant $1 \%$ and had a positive coefficient. This implies income derived from home gardening encourages home gardeners to participate more in farming as they generate income. This suggests that a unit increase of $1 \%$ in total household monthly income from gardening led to increased participation in home gardens by $0.0529 \%$. This means that involvement in home gardens increases as household monthly income increases. This result agrees with Malahlela (2014) that higher household monthly income does play a significant role in the home garden through sales of farm produce to generate income for the household.

The farm size was found to have a negative coefficient and was statistically significant at $5 \%$. This implies that a unit increase of $1 \mathrm{Ha}$ in farm size led to a decrease in ownership of home gardens by $0.0751 \%$. The households involved in participating in home gardens mentioned that they are less willing to participate in home gardens that require a large piece of land due to finances and the age of the households who cannot keep up working larger home gardens. These results agree with Ngema (2017) that most households are not willing to work larger home gardens due to different factors such as finance and age being the leading factors limiting households.

\section{CONCLUSIONS AND RECOMMENDATIONS}

The objective of the paper was to measure socio-economic factors affecting home gardens as the livelihood strategy in rural areas of the Eastern Cape Province of South Africa. Agriculture is one sector that makes efforts to address issues of rural development. The findings from two hundred households in the study area indicate that home gardens are economical and have social implications on the livelihood system. Home gardens contributed immensely in rural households as a living strategy as they provide food for home consumption and income generated. Even though home gardening was prominent in the study area, some households were seasonal home gardeners. Some did little or no home gardening because of water, lack of inputs, diseases, credit constraints, and theft challenges. The participation/ownership of home gardens were influenced positively by location, years spent in school, total household income, and land ownership, while age, off-farm income, and family size adversely influenced home gardens. Therefore, the study recommends that government credit institutions must be made available for rural people at a cheap interest rate so that they can access them. The community and government must be involved in education training and agricultural programs of luring young people to participate in agricultural activities to ensure they have the necessary skills. There is a need for the government to design the home garden program as the strategy of alleviating poverty in South Africa due to the significant contribution in alleviating poverty, especially the consumption expenditure of the households. Extension personnel must be made available to disseminate information, conduct training and innovative techniques used for farming so that these households can be more hands-on in-home gardens and improve their food production. 


\section{REFERENCES}

ADHIKARI, B. 2005. Poverty, Property Rights, and Natural Resource: Understanding Distributional Implications of Common Property Resource Management. Env. Dev. Eco. 10: 7-31.

BAIPHETHI M. N. 2009. The contribution of subsistence farming to food security in South Africa. Agrekon.48(4), 22-423.

EASTERN CAPE DEVELOPMENT CORPORATION (ECDC). (2013), About the Eastern Cape: District Maps. Available on: http://www.ecdc.co.za/the_eastern_cape/district_map. Accessed 15 October 2019

EKEPU, D. \& TIRIVANHU, P. 2014. Assessing socio-economic factors influencing adoption of legume-based multiple cropping systems among smallholder sorghum farmers in Soroti, Uganda. S. Afr. J. Agric. Ext. 44(2): $195-215$.

ETWIRE, P. M., DOGBE, W., WIREDU, A. N., MARTEY, E., ETWIRE, E., OWUSU, R. K. \& WAHAGA, E. 2013. Factors influencing farmer's participation in agricultural projects: the case of the agricultural value chain mentorship project in the northern region of Ghana. Legon Uccra: CSIR-Savanna Agricultural Research Institute.

GALHENA H, RUSSELL F. \& KARIM M. 2013. Home gardens: a promising approach to enhance household food security and wellbeing. Agr. Foo. Sec. 2:8.

HLOMENDLINI, P. H. 2015. Key Factors Influencing Smallholder Market Participation in the Former Homelands of South Africa: Case Study of the Eastern Cape. MSc Dissertation, Published. South Africa: Stellenbosch University.

MALAHLELA, N. D. 2014. Socioeconomic Contribution of Community Food Gardens to the Livelihoods of rural households in Lepelle-Nkumpi Local Municipality of Limpopo Province, South Africa. Published MSc. Dissertation, University of Fort Hare, RSA.

MATEBENI, F. 2018. Measuring rural household food security in the Nkonkobe local Municipality, Eastern Cape Province of South Africa. MSc. Dissertation, University of Stellenbosch, RSA.

MCATA, B. 2019. Garden ownership as a solution to food insecurity in urban areas of South Africa: the case of food gardens in Alice Town, Eastern Cape Province. J. Agr. Rur. Dev. 3 (53): $215-224$.

MDODA, L. \& OBI, A. 2019. Analysis of profitability of smallholder Irrigated food plots in the Eastern Cape Province of South Africa. J. Agr. Rur. Dev., 3 (53): 225-232.

MDODA, L., MELENI, S., MUJURU, N. \& ALAKA, K. O. 2019. Agricultural Credit Effects on Smallholder Crop Farmers Input Utilisation in the Eastern Cape Province, South Africa. J. Hum. Eco. 66 (1-3): 45-55. 
MOKONE, N. W. 2016. The economic contribution of backyard gardens in alleviating poverty in the rural communities of Bojanala Platinum District Municipality, in North West Province, South Africa. Published MSc. Dissertation, University of South Africa, RSA.

MONDE, N., FRASER, G., BOTHA, J. J. \& ANDERSON, K. 2006. Making home gardening a viable option in rural areas of South Africa: the case study of Guquka and Khayalethu in central Eastern Cape. Retrieved from: http://www.uwsp.edu/cnr/gem/Conference\%20Procceedings/Track5Papers/Monde\%20Tr ack5\%20EMSU\%20paper\%20FinalComplete.pdf. Accessed On 11 May 2020.

MONTSHWE, D. B. 2006. Factors affecting participation in mainstream cattle markets by smallscale cattle farmers in South Africa. Published MSc. Dissertation, University of Free State, RSA.

MQIKELA, N. 2014. The Impact of Land and Agrarian Reforms on Poverty Alleviation: Lessons from the Jay Dee Rovon Workers Trust and Mon Desire In Joubertina, Eastern Cape-South Africa. Publishing M. Dissertation, University of Fort Hare, RSA.

MUCHARA, B. 2010. Analysis of food value chain in smallholder crop and livestock enterprises in Eastern Cape Province of South Africa. Unpublished MSc Thesis, University of Fort Hare, RSA.

MUSOTSI, A. A, SIGOT, A. J. \& ONYANGO, M. O. A. 2008. The role of home gardening in household food security in butere division of Western Kenya. Afri. J. Foo. Agr. Nut. Dev..8 (4): $375-390$.

NGEMA, P. Z. 2017. Factors affecting the food security status and participation in food security intervention programmes in Maphumulo. Published MSc. Dissertation, University of Zululand, RSA.

NONTU, Y. \& TARUVINGA, A., 2021. Determinants of home gardening participation among rural households: evidence from Ingquza hill local municipality, South Africa. Journal of Agribusiness and Rural Development, 60(2), pp.213-220.

OLUWASOLA, A. O, MONDE, N, ISAAC, A. \& SUNDAY, O. 2013. The Role of Home Gardens in Household Food Security in Eastern Cape: A Case Study of Three Villages in Nkonkobe Municipality. J. Agr. Sci.; 6 (1): 126-136.

ORTMANN, G. F. \& KING, R. P. 2006. Small-scale farmers in South Africa: Can agricultural cooperatives facilitate access to input and product markets? Agrekon. 46 (2): 219 - 244.

RODRIGUE, C. G, ADANDÉ, B. FANDOHAN, V. S., FRANCK, R. I, ROMAIN, G. K., \& ACHILLE, E. A. 2015. Factors affecting home gardens ownership, diversity and structure: a case study from Benin. J. Eth. Eth. 11: 56.

TABOKA, S. K. 2016. Evaluation of the impact of backyard gardens on household Incomes in Southern District, Botswana. Published M. Dissertation, Egerton University, Botswana. 
S. Afr. J. Agric. Ext.

Mdiya \& Mdoda

Vol. 49 No. 3, 2021: 1-15

http://dx.doi.org/10.17159/2413-3221/2021/v49n3a12823

(License: CC BY 4.0)

WOOLDRIDGE, J. M. 2009. Introductory Econometrics, a Modern Approach, Fourth Edition. Michigan State University. 